\title{
Spatial Estimation of Soil Erosion Risk Using RUSLE Approach, RS, and GIS Techniques: A Case Study of Kufranja Watershed, Northern Jordan
}

\author{
Yahya Farhan, Dalal Zregat, Ibrahim Farhan \\ Department of Geography, Faculty of Arts, The University of Jordan, Amman, Jordan \\ Email: yahyafarhan2100@outlook.com
}

Received September 1, 2013; revised October 1, 2013; accepted October 28, 2013

Copyright (C) 2013 Yahya Farhan et al. This is an open access article distributed under the Creative Commons Attribution License, which permits unrestricted use, distribution, and reproduction in any medium, provided the original work is properly cited.

\begin{abstract}
Wadi Kufranja catchment $\left(126.3 \mathrm{~km}^{2}\right)$, northern Jordan, was selected to estimate annual soil loss using the Revised Universal Soil Loss Equation (RUSLE), remote sensing (RS), and geographic information system (GIS). RUSLE factors (R, $\mathrm{K}, \mathrm{LS}, \mathrm{C}$ and $\mathrm{P}$ ) were computed and presented by raster layers in a GIS environment, then multiplied together to predict soil erosion rates, and to generate soil erosion risk categories and soil erosion severity maps. The estimated potential average annual soil loss is 10 ton $\mathrm{ha}^{-1} \cdot \mathrm{year}^{-1}$ for the catchment, and the potential erosion rates from recognized erosion classes ranged from 0.0 to 1850 ton $^{-1} \mathrm{ha}^{-1} \cdot \mathrm{year}^{-1}$. About $42.1 \%$ (5317.23 ha) of the catchment area was predicted to have moderate risk of erosion, with soil loss between $5-25$ ton ha $^{-1} \cdot$ year $^{-1}$. Risk of erosion is severe to extreme over $31.2 \%$ (3940.56 ha) of the catchment, where calculated soil loss is $25-50$ and $>50$ ton $\cdot \mathrm{ha}^{-1} \cdot \mathrm{year}^{-1}$. Apart from the gentle slopes of the alluvial fan (Krayma town and surroundings), the lower and the middle reaches of the watershed suffer from severe to extreme erosion risk. High terrain, slope steepness, removal of vegetation, and poor conservation practices are the most prominent causes of soil erosion. This investigation demonstrates that remote sensing (RS) and GIS technologies are effective tools in modeling erosion, thus enabling extraction of significant information for implementing soil conservation plans in the north Jordan highlands.
\end{abstract}

Keywords: Jordan; Soil Erosion; Risk Mapping; Severity; RUSLE; Wadi Kufranja

\section{Introduction}

Jordan is currently suffering from serious soil erosion. This is by no means a new problem for the country but one that has intensified recently as human population pressures on the land increase [1]. Soil erosion, a gradual process, removes soil particles by runoff, thus causing soil to deteriorate [2]. The accumulation of 10 to 15 centimeters of soil behind newly constructed walls in a single season indicates the severity of the problem. Erosion of the topsoil leads to declining soil productivity, thus restricting the area of potential future agriculture. Modern soil conservation and agricultural reorganization provide a wide choice of remedial measures to reduce soil erosion rates in the country [3], and are considered imperative for the country's future wellbeing. Eroded soil materials are deposited over wadi floors and agricultural lands, irrigation canals, even on roads, and more seriously in reservoirs.
Several qualitative and quantitative investigations have tackled soil erosion in Jordan. The Natural Resources Authority [4] reported that heavy rain caused severe erosion, and the resultant deposition filled the King Abdullah Canal (East Ghor canal), which took three months to clear at a cost of US\$4.5 million. In the Southern Ghor region, the Ministry of Agriculture estimated an erosional loss of 1100 hectares of arable land out of 5400 hectares in the southern Ghor region.

Soil erosion losses for all catchments in Jordan are estimated at 1.328 million ton year $^{-1}$, which amounts to a loss of $0.14 \mathrm{~cm}$ over the entire area [5]. The soil erosion map of the FAO et al. [6] shows most of Jordan within 10 - 50 ton $\cdot \mathrm{ha}^{-1} \cdot$ year $^{-1}$ due to water erosion. Part of the highland falls within $50-200$, and $>200$ ton $\cdot \mathrm{ha}^{-1} \cdot$ year $^{-1}$. Harza [7] estimated the total sediment inflow to King Talal Reservoir at about $1.7 \mathrm{Mm}^{3} \cdot \mathrm{year}^{-1}$, while Lara [8] gave a total sediment volume of $3.84 \mathrm{Mm}^{3} \cdot \mathrm{year}^{-1}$. Field measurement of soil erosion (1989-1995) by runoff in 
Jordan (Table 1) has been assessed over small plots [9, 10] with sub-humid Mediterranean [11], semi arid [12], and arid climates [13].

Soil erosion risk mapping has evaluated soil erosion susceptibility qualitatively for three Jordanian watersheds [14-16]. Airphoto interpretation of geomorphic units has been used, overlain by a system of soil erosion susceptibility classes $[17,18]$ arrived at classes from slight to extremely high.

Recently, the Universal Soil Loss Equation (USLE) model in conjunction with RS and GIS technology has been used to predict the annual soil loss in an area of the Balqa district, central Jordan [19] and the southern part of the Yarmouk valley in northern Jordan [20]. Estimated average soil loss was 78 ton ha $^{-1} \cdot$ year $^{-1}$ (Balqa District), and 5 to $>25$ ton $\cdot \mathrm{ha}^{-1} \cdot$ year $^{-1}$ (Yarmouk valley). Erosivity factor $(\mathrm{R})$ and soil erodibility factor $(\mathrm{K})$ were calculated using both USLE and RUSLE models, then an estimate of soil loss in three north Jordan locations was obtained using the RUSLE model. Average soil loss ranged from 3.4 ton $\cdot$ ha $^{-1} \cdot$ year $^{-1}$ to 13 ton $\cdot$ ha $^{-1} \cdot$ year $^{-1}[21]$.

This study attempts to employ the revised version of the Universal Soil Loss Equation (RUSLE), combined with RS and GIS technologies to: 1) estimate the potential soil loss from areas within the Wadi Kufranja catchment, 2) produce soil erosion risk and soil erosion severity maps, and 3) identify areas of critical soil erosion conditions which require urgent need for appropriate conservation measures and land management.

\section{Study Area}

Wadi Kufranja catchment constitutes the present study area. It locates in the northern highlands of Jordan, and lies between $32^{\circ} 14^{\prime} \mathrm{N}$ to $32^{\circ} 22^{\prime} \mathrm{N}$ and $35^{\circ} 21^{\prime} \mathrm{E}$ to $35^{\circ} 47^{\prime} \mathrm{E}$ (Figure 1). The watershed area is $126.3 \mathrm{~km}^{2}(12,630 \mathrm{ha})$, with elevations $1173 \mathrm{~m}$ asl (above sea-level) to $\sim 329 \mathrm{~m}$ bsl (below sea-level) over a distance of only $23 \mathrm{~km}$. The upper wadi consists of maturely dissected terrain, with broad valley forms and smooth interfluves. In the middle and lower parts, rejuvenation resulted in a narrow, incised, steepsided gorge. Large and small arcuate scars and hummocky topography indicate past landside episodes, probably of Pliocene and Quaternary age $(<5 \mathrm{Ma})$ $[22,23]$. The geology is dominated by Upper Cretaceous marly clay and marly limestone of the Ajlun series, which closely influences the basin soils. Vertisolic (cracking soil), typic xerochrepts, and lithic soils cover the largest area in the watershed, while other types comprise alluvial (wadi infill) soils, variable types on slopes, and soils of the alluvial fan at the lower part of Wadi Kufranja, west of Krayma town.

About $10 \%$ of the watershed is bare rock, and truncation of upper soil horizons is widespread; fully developed soil profiles are rare. Erosion exposes more loosely struc-
Table 1. Soil erosion rates estimated for three locations in the country.

\begin{tabular}{cccc}
\hline Area & Climate & $\begin{array}{c}\text { Splash erosion } \\
\left(\text { ton }^{-1} \mathrm{~h}^{-1} \cdot \mathrm{year}^{-1}\right)\end{array}$ & $\begin{array}{c}\text { Runoff erosion } \\
\left(\text { ton }^{-1} \mathrm{ha}^{-1} \cdot \mathrm{year}^{-1}\right)\end{array}$ \\
\hline Al Salt & $\begin{array}{c}\text { Sub-humid } \\
\text { Mediterranean }\end{array}$ & $3.24-21.42$ & $0.581-2.382$ \\
Muwaqar & Semi arid & $2.59-16.3$ & 1.05 \\
Azraq & Arid & $2.8-7.39$ & 0.14 \\
\hline
\end{tabular}

Source: [11-13].

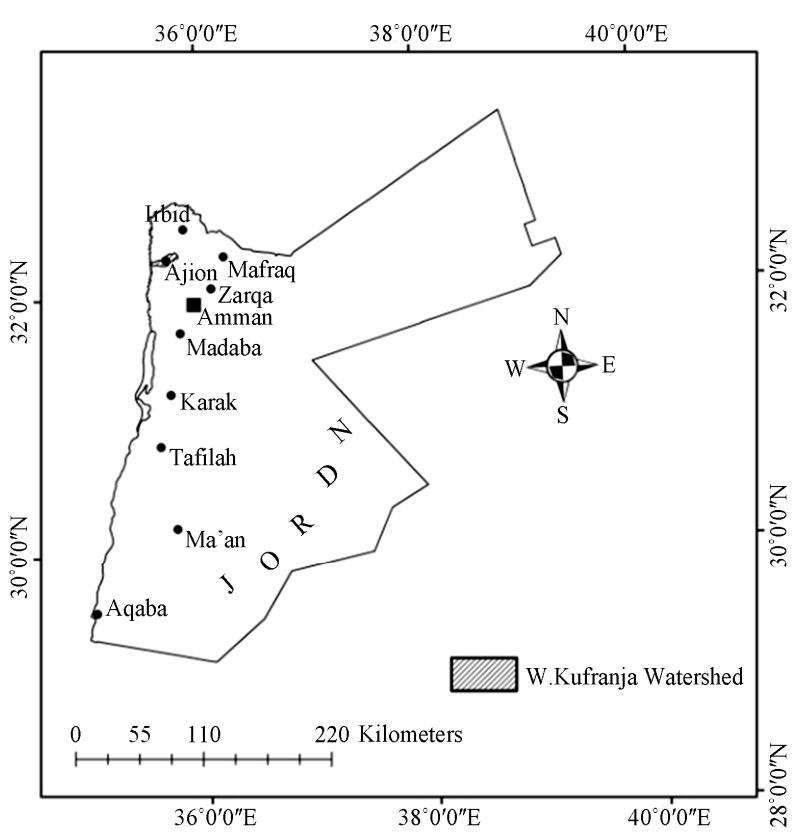

Figure 1. The study area.

tured subsoil, which accelerates further erosion [1,24]. Climate is classified as "dry Mediterranean" in the upper catchment and "semi-arid and arid" in the lower parts. Mean annual rainfall ranges from $630.5 \mathrm{~mm}$ at Ajlune town to $267.8 \mathrm{~mm}$ at Wadi Kufranja station (east of Krayma) close to the Ghor. Most meteorological stations in the watershed record 30 - 50 rain days per year [25]. Severe storms with maximum daily intensity of $2.1-5$ $\mathrm{mm} \cdot \mathrm{hr}^{-1}$ are common [26]. Severe soil erosion is therefore predictable. However, $95 \%$ of the precipitation falls from November to March ( $70 \%$ in Dec-Feb). Winter monthly temperatures of $3^{\circ} \mathrm{C}-5^{\circ} \mathrm{C}$ are recorded in higher parts of the watershed; summer months average $22^{\circ} \mathrm{C}$ $25^{\circ} \mathrm{C}$. In Krayma (in the Ghor, the Jordan Rift-floor) the average annual temperature is $24^{\circ} \mathrm{C}$, with summer months reaching $40+^{\circ} \mathrm{C}$. Frost-days number $5-15$ per year [25] Land-cover types vary from natural vegetation (forests) mixed with crop-land. Four scattered associations of forests are distinguished throughout the watershed: broadleaved forest of Quercus coccifera (Kermes oak), broadleaved forest of Quercus aegilops (Decideous oak, or 
Ithaburensis), coniferous forest of Pinus halepensis (Aleppo pine), and mixed forest of oak and Olea europaea (Wild olive). These forests have suffered severe anthropogenic stresses. There is overgrazing especially by goats, which graze the stubble of wheat, barley, and field crops (tomatoes, lentils, chick-peas), vines and olives. Collection of fuel and charcoal-wood is an added stressor [27]. The worst effect of the cultivation pattern and land cover changes is that the soil surface is bare during the moist winter months. Low rainfall interception by vegetation allows destructive splash erosion. Once soil particles are displaced, nothing hinders their displacement downslope. Consequently, environmental degradation including soil erosion is widespread throughout Wadi Kufranja watershed [24]. Five types of land use/cover exist in the watershed; residential and commercial areas (7.52\%), forest $(18.53 \%)$, mixed agricultural $(51.23 \%)$, open rangeland $(13.30 \%)$ and bare soil $9.42 \%$ [28]. The objective of this study is to estimate soil erosion loss and severity for Wadi Kufranja, which in turn can be used as a representative example for other comparable watersheds characterized by similar rainfall, topography, soil, and land use in the northern highlands of Jordan.

\section{Materials and Methods}

\section{Soil Loss Estimation Method}

Many accurate soil erosion models were developed over the last four decades to assess soil erosion risk at different levels: single slope, river/wadi catchment, regional and global scales $[29,30]$. Among these, the Univeral Soil Loss Equation (USLE) [31,32], European Soil Erosion Model (EUROSEM) [33], Soil Erosion Model for the Mediterranean Region (SEMMED) [34], Water Erosion Prediction Model (WEPP) [35,36], the Soil and Water Assessment Tool (SWAT) [37], and the Chemicals, Runoff, and Erosion from Agricultural Management Systems (CREAMS) [38]. The USLE model has been widely used worldwide over the last 40 years to estimate soil erosion risk. The requirements of the model, in terms of intensive data and computation, reinforce the elaboration of more accurate and less demanding ones. The Revised Universal Soil Loss Equation (RUSLE) is considered the alternative improved version of the proto USLE model [39-41]. Although RUSLE adopted the same empirical principles and the fundamental structures as the USLE model, substantial modifications of the USLE were carried out which cover all aspects of the model to assist with computations and wider applications especially in developing countries. New term values, corrections, factor algorithms, slope morphology, and elaborated approaches for calculating the parameters of the model were introduced. It accommodates more accurate methods to estimate of rainfall erosivity (R), soil erodi- bility (K), slope length and steepness (LS), land cover management $(\mathrm{C})$, and conservation practice $(\mathrm{P})$ factors [42]. Information on factors leading to soil erosion can be utilized as a guide for formulating appropriate soil conservation and land management plans. The Revised Universal Soil Loss Equation (RUSLE) is frequently used to estimate the magnitude of soil erosion loss from watershed areas, the spatial distribution of soil erosion severity, and delimiting sites vulnerable to soil erosion for both agricultural and forested watersheds [30,42-48]. Finally, the RUSLE model has several advantages: 1) it is easy to implement and understand from a functional perspective [32], 2) is compatible with the Geographic Information System (GIS), and 3) the data requirements to implement the model are not too complex or unattainable especially in a developing country [49]. However, the watershed heterogeneity (i.e. variations in soil, land use/cover, topography) and spatial rainfall variability led to a prominent variation in the predicted soil loss, therefore, the RUSLE model is normally executed in conjunction with a raster-based GIS, to predict erosion potential on a cell by cell basis [49]. Hence, watersheds need to be discretized into small homogenous units. In the present study, grid cells of $30 \mathrm{~m} \times 30 \mathrm{~m}$ size were determined before making the computation of the physical characteristics of these cells such as: slope, land use, and soil type all of which affect soil erosion processes in different cells of the watershed. Such a procedure is essential to create a uniform spatial analysis environment for GIS modeling [30,42].

The RUSLE model was developed as an equation representing the main factors controlling soil erosion, namely climate, soil characteristics, topography, and land cover management. The equation is expressed as:

$$
\mathrm{A}=\mathrm{R} \times \mathrm{K} \times \mathrm{LS} \times \mathrm{C} \times \mathrm{P}
$$

where,

$\mathrm{A}=$ computed annual soil loss per unit area [ton $\cdot$ ha $^{-1} \cdot$ year $\left.^{-1}\right]$.

$\mathrm{R}=$ runoff erosivity factor (rainfall and snowmelt) in $\left[\mathrm{MJ} \mathrm{mm} \cdot \mathrm{ha}^{-1} \cdot \mathrm{hr}^{-1} \cdot\right.$ year $^{-1}$ ].

$\mathrm{K}=$ soil erodibility factor (soil loss per erosion index unit for a specified soil measured on a standard plot, 22.1 $\mathrm{m}$ long, with uniform $9 \%\left(5.16^{\circ}\right)$ slope, in continuous tilled fallow) [ton $\cdot h a \cdot h r \cdot h a^{-1} \cdot \mathrm{MJ}^{-1} \cdot \mathrm{mm}^{-1}$ ].

$\mathrm{L}=$ slope length factor (ratio of soil loss from the field slope length to soil loss from standard $22.1 \mathrm{~m}$ slope under identical conditions) (dimensionless).

$\mathrm{S}=$ slope steepness factor (ratio of soil loss from the field slope to that from the standard slope under identical conditions) (dimensionless).

$\mathrm{C}=$ cover-management factor (ratio of soil loss from a specified area with specified cover and management to that from the same area in tilled continuous fallow) (di- 
mensionless).

$\mathrm{P}=$ support practice factor (ratio of soil loss with a support practice - contour tillage, strip-cropping, terracing - to soil loss with row tillage parallel to the slope (dimensionless).

In the present study, annual soil loss rates and severity were computed based on RUSLE in GIS environment using Arc GIS 10.1 and ERDAS Imagine 8.5, and the associated GIS packages. Land use/cover information for the watershed was obtained from LANDSAT ETM+ 2009, and revised and updated using Google Earth pro (2011). Rainfall data for calculation of rainfall erosivity (R) was obtained from the Ministry of Water and Irrigation, and the soil data was acquired from 1995 national soil survey maps and reports [50] along with 115 field soil samples for analyzing soil properties. NDVI values were generated and mapped from a LANDSAT image, and used to determine the $\mathrm{C}$ factor and to verify land use/cover information.

\section{Calculation of RUSLE Factors}

\subsection{Rainfall Erosivity (R)}

$\mathrm{R}$ factor is the quantitative expression of the erosivity of local average annual precipitation and runoff causing soil erosion. It is a measure of the erosive force of a specific rainfall. $\mathrm{R}$-value is greatly affected by the volume, intensity, duration and pattern of rainfall whether for single storms or a series of storms, and by the amount and rate of the resulting runoff. Differences in the $\mathrm{R}$ factor reflect differences in precipitation patterns between regions. Areas with low slope degree have low erosivity $R$ values which imply that flat areas would increase the water ponding on the surface, thus protecting soil particles from being eroded by rain drops. Large numbers of $\mathrm{R}$ factor indicate more erosive weather conditions. $\mathrm{R}$ values can be obtained from isoerodent maps, tables or calculated from historic data [41]. A period of 20 - 25 year is recommended for computing the average $\mathrm{R}$ [32]. Rainfall data of 30 years average for five weather stations distributed over the watershed were used to calculate $\mathrm{R}$ values based on the equation elaborated by Eltaif et al. [51] who expanded the equations of RUSLE and USLE developed by Renard and Freimund [40]. The elaborated equation has been tested in northern parts of Jordan using pluviometric data from 18 stations. The achieved mean annual erosivity index (R), and mean annual precipitation ( $\mathrm{mm}$ ) were found to be highly correlated $(r=0.99)$. The equation of Eltaif et al. [51] used to compute $\mathrm{R}$ values is the following:

$$
\mathrm{R}=23.61 \times \mathrm{e}^{(0.0048 \mathrm{p})}
$$

where $\mathrm{p}$ is the mean annual precipitation.

In terms of GIS layers, each weather station was rep- resented by a point. The Inverse Distance Weighted (IDW) interpolation method in GIS was used to generate a raster map for $\mathrm{R}$ factor.

Table 2 illustrates the computed rainfall erosivity (R) values using data from five weather stations across the Wadi Kufranja watershed (and two additional stations close to the upper and lower parts of the watershed). The $\mathrm{R}$ values in this study were in the range (85.4 - 486.9).

\subsection{Soil Erodability Factor (K)}

Soil erodability factor $(\mathrm{K})$ expresses the soil susceptibility to detachment and transport of soil particles (grains or crumbs), under an amount and rate of runoff for a specific rainfall, measured under standard plot. The $\mathrm{K}$ factor is rated on a scale from 0 to 1 , where 0 refers to soils with least susceptibility to erosion and 1 refers to soils which are highly susceptible to erosion by water. Generally, soils become of low erodibility if the silt content is low, regardless of corresponding high content in the sand and clay fractions [29]. The factor was computed using the following equation $[32,41]$ :

$$
\begin{aligned}
\mathbf{K}= & 27.66 \mathbf{m}^{1.14} \times 10^{-8} \times(12-\mathbf{a})+0.0043 \times(\mathbf{b}-2) \\
& +0.0033 \times(\mathbf{c}-3)
\end{aligned}
$$

where:

$\mathbf{K}=$ Soil erodibility factor (ton $\left.\cdot \mathrm{hr}^{-1} \cdot \mathrm{ha}^{-1} \cdot \mathrm{MJ} \cdot \mathrm{mm}\right)$.

$\mathbf{m}=(\mathrm{Silt} \%+\mathrm{Sand} \%) \times(100-$ clay $\%)$.

$\mathbf{a}=\%$ organic matter.

$\mathbf{b}=$ structure code: 1) very structured or particulate, 2) fairly structured, 3) slightly structured, and 4) solid.

$\mathbf{c}=$ profile permeability code: 1) rapid, 2) moderated to rapid, 3) moderate, 4) moderate to slow, 5) slow, 6) very slow.

The $\mathrm{K}$ factor is influenced by intrinsic soil properties related to soil profile parameters such as: percent silt (0.002 - $0.1 \mathrm{~mm})$, percent sand $(0.1-2 \mathrm{~mm})$, percent organic matter, soil structure and permeability [43]. Soil types in the study area were identified from the National Soil Map and Land Use Project [50], and the associated reports. Then 115 soil samples were collected from the field representing the different soil types over the watershed. Location of these samples was controlled by GPS. Applying the Equation (2) to generate GIS layer, it was important to generate digital maps of soil properties used in the equation. These were: sand, silt, clay and organic matter, and permeability classes. The maps were generated using the inverse distance weighted (IDW) interpolation method on point data (vector layers) for the soil samples analyzed. The map of $\mathrm{K}$ factor was checked by computing values obtained from the equation with those obtained from a soil erodibility Nomograph [52]. Results were nearly identical and variations were obtained to the 
Table 2. Rainfall erosivity $(R)$ values.

\begin{tabular}{ccc}
\hline Station & $\mathrm{P}(\mathrm{mm})$ & $(\mathrm{R})\left(\mathrm{MJ} \cdot \mathrm{mm} \cdot \mathrm{ha}^{-1} \cdot \mathrm{hr}^{-1} \cdot \mathrm{year}^{-1}\right)$ \\
\hline W. Kufranja & 267.8 & 85.4 \\
Ras Muneif & 562.7 & 351.6 \\
Kufranja & 593.2 & 407.1 \\
Ajlun & 630.5 & 486.9 \\
Anjara & 600 & 420.6 \\
\hline
\end{tabular}

third digital. Therefore the map was adopted to apply it in the RUSLE model. The classes of soil structure of $\mathbf{b}$ variable (Equation (2)) were identified using soil texture as described by Edmonds et al. [53].

\subsection{Slope Length and Steepness Factor (LS)}

The (LS) factor expresses the effect of local topography on soil erosion rate, combining effects of slope length (L) and slope steepness (S). Thus, LS is the predicted ratio of soil loss per unit area from a field slope from a $22.1 \mathrm{~m}$ long, 9\% $\left(5.16^{\circ}\right)$ slope under otherwise identical conditions. The Digital Elevation Model (DEM) with a resolution of $30 \mathrm{~m}$ was used to calculate $\mathrm{L}$ and $\mathrm{S}$ parameters. The DEM (Figure 2) was provided by the Royal Jordanian Geographic Centre (RJGC). The following equation was adopted to compute the LS factor [54]:

$$
\mathbf{L S}(\mathbf{r})=(\mathbf{m}+\mathbf{1}) \times\left[\mathbf{A}(\mathbf{r}) / \mathbf{a}_{\mathbf{0}}\right]^{\mathbf{m}} \times\left[\operatorname{sinb}(\mathbf{r}) / \mathbf{b}_{\mathbf{0}}\right]^{\mathbf{n}}
$$

where: $\mathbf{A}(\mathbf{r})=$ upslope contributing area per unit contour width; $\mathbf{b}(\mathbf{r})$ is $=$ slope; $\mathbf{m}=0.6 ; \mathbf{n}=1.3$ are parameters, $\mathbf{a}_{\mathbf{o}}$ $=22.1 \mathrm{~m}=72.6 \mathrm{ft}$ is the length; $\mathbf{b}_{\mathbf{0}}=0.09=9 \%=5.16$ degree is the slope of the standard USLE plot.

The spatial analyst toolkit of the GIS software was used to generate raster layers of slope gradient (degrees), and from the hydrology toolkit the flow direction and then the flow accumulation were calculated. The output layers were then used in the GIS raster calculator interface to generate the map of LS factor based on the equation using the flow accumulation grid as follows:

$$
\begin{aligned}
\mathbf{L S}= & \operatorname{Pow}([\text { Flow Acc }] \times \text { resolution } / 22.1,0.6) \\
& \times \operatorname{Pow}((\operatorname{Sin}[\text { slope gradient }] \times 0.01745) / 0.09,1.3)
\end{aligned}
$$

As the slope length L increases, the total soil loss and soil erosion per unit increase; as a result of progressive accumulation of runoff in the down slope. As the slope steepness increases, the soil erosion also increases as a result of increasing the velocity and erosivity of runoff. However, Zhang et al. [55] developed more accurate method to calculate the LS factor to estimate soil erosion at regional landscape scale. Breakes in slope were identified from DEM and utilized to locate channel networks, convergence flow areas, and soil erosion and deposition areas.

\subsection{Crop Management Factor}

The crop management factor (C) expresses the effect of cropping and management practices on the soil erosion rate [41], and is considered the second major factor (after topography) controlling soil erosion. It expresses the protection of soil by cover-type and density. $\mathrm{C}$ is thus a relation between erosion on bare soil and erosion observed under a cropping system. The $\mathrm{C}$ factor combines plant cover, the level of its production, and the associated cropping techniques. It varies from 1 on bare soil to $1 / 1000$ under forest, $1 / 100$ under grasslands and cover plants, and 1 to $9 / 10$ under root and tuber crops $[21,56]$. An increase in the cover factor indicates a decrease in exposed soil, and thus an increase in potential soil loss.

Mapping was undertaken using an on-screen digitizing procedure to produce land use/cover map, which transferred to crop management factor $\mathrm{C}$ and support practice factor $\mathrm{P}$ layers as a factors in RUSLE. Digitizing was carried out to generate polygons by inclosing areas (classes), with specific boundaries. After that field survey was performed to verify and correct results of land use/ cover maps. The Look Up Tool in Arc GIS was used to reclassify the land use/cover map according to its $\mathrm{C}$ values (Table 3), which were assigned based on Wischmeier and Smith [32] and previous studies undertaken in northen Jordan [21,57].

The normalized difference vegetation index (NDVI) (by computing the ratio

[Band 4-Band 3]/[Band $4+$ Band 3]) was derived from LANDSAT ETM + image (2009) and used to calculate the spectral ground-based data, which shows the highest correlation with the above-ground biomass [58]. The relationship between $\mathrm{C}$ and NDVI was determined (Figure 3) as $\mathrm{C}=(-0.7388 \times \mathrm{NDVI}+0.4948)$, where the $\mathrm{C}$ value in each land cell can be specified.

\subsection{Conservation Practice Factor (P)}

Conservation practice factor (P) in the RUSLE model expresses the effect of conservation practices that reduce the amount and rate of water runoff, which reduce erosion. It is the ratio of soil loss with a specific support practice on croplands to the corresponding loss with slope-parallel tillage [32,59]. It includes different types of agricultural management practices such as: strip cropping, contouring and terracing. A "P factor" map was derived from the land use/cover-type maps, and each value of $\mathrm{P}$ was assigned to each land use/cover type and slope (Table 4) [32]. The Look Up Tool in Arc GIS was used to reclassify the land use/cover and slope length maps according to its $P$ value. 


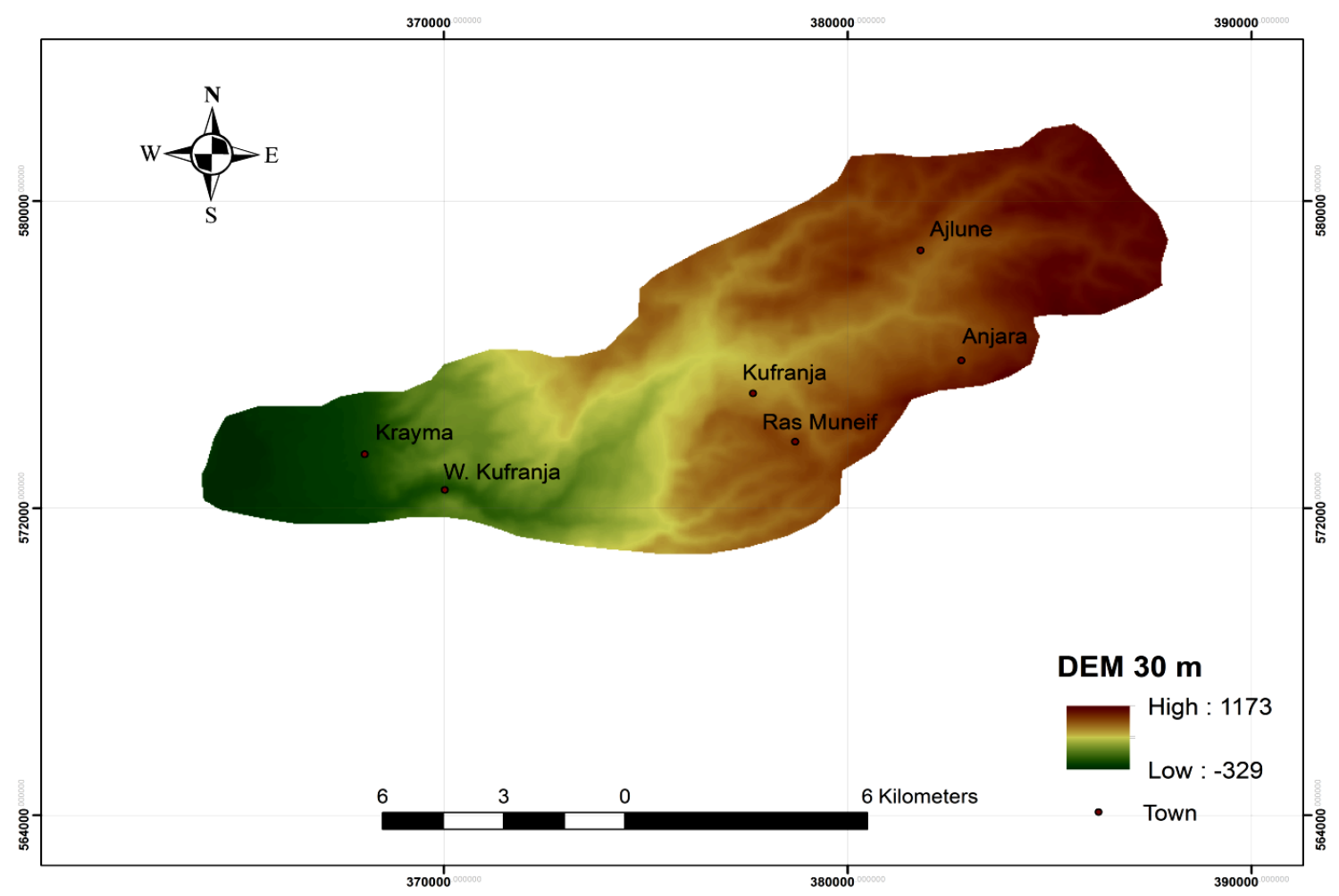

Figure 2. The digital elevation model.

Table 3. $\mathrm{C}$ factor values for different land cover-types.

\begin{tabular}{ccc}
\hline Landuse/Cover & NDVI-Values & C-Values \\
\hline Bare soil & -0.01 & 0.50 \\
Forest area & 0.6 & 0.05 \\
Mixed agricultural area & 0.4 & 0.20 \\
Open Rangeland area & 0.2 & 0.35 \\
\hline
\end{tabular}

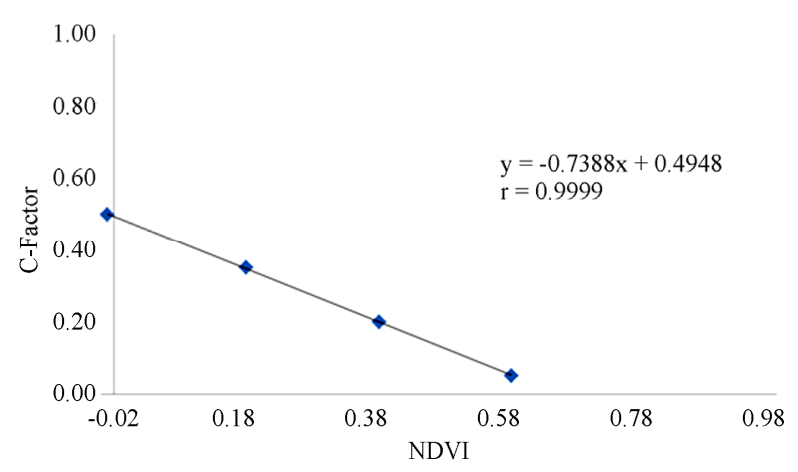

Figure 3. Correlation between $\mathrm{C}$-factor values and NDVI values.

\section{Results and Discussion}

The data layers (maps) extracted for K, LS, R, C, and P factors of the RUSLE model were integrated within the raster calculator option of the Arc GIS spatial analyst in order to quantify, evaluate, and generate the maps of soil
Table 4. Support practices factor (P).

\begin{tabular}{ccc}
\hline Land Use Type & Slope - \% & P Factor \\
\hline $0-5$ & 0.10 \\
$5-10$ & 0.12 \\
Agriculture & $10-20$ & 0.14 \\
& $20-30$ & 0.19 \\
& $30-50$ & 0.25 \\
Other land & $50-100$ & 0.33 \\
\hline
\end{tabular}

erosion risk and severity for Wadi Kufranja. The rainfall erosivity factor $(\mathrm{R})$ for five weather stations was found to be in the range of 85.5 and $487 \mathrm{MJ} \cdot \mathrm{mm} \cdot \mathrm{ha}^{-1} \cdot \mathrm{hr}^{-1} \cdot \mathrm{year}^{-1}$ (Figure 4). The distribution of $\mathrm{R}$ values assumed to be varied and consistent with annual precipitation across the watershed. The highest $\mathrm{R}$ values (413 - 487 $\mathrm{MJ} \cdot \mathrm{mm} \cdot \mathrm{ha}^{-1} \cdot \mathrm{hr}^{-1} \cdot$ year $^{-1}$ ) prevail in the upper catchment (humid areas of Kufanja-Ajlune-Anjara), and the lowest $\left(85.5\right.$ - $\left.164 \mathrm{MJ} \cdot \mathrm{mm} \cdot \mathrm{ha}^{-1} \cdot \mathrm{hr}^{-1} \cdot \mathrm{year}^{-1}\right)$ occurs in the arid Krayma area. The map of $\mathrm{K}$ values for the entire catchment (Figure 5) shows a maximum value of 0.063 ton $\cdot h a \cdot \mathrm{hr}^{-1} \cdot \mathrm{MJ}^{-1} \cdot \mathrm{mm}^{-1}$ in the middle and upper catchment, especially where vertisols and typic xerochrepts soils are dominant, and were landslide compexes characterized the clay marly and the marly limestone units exist. The 


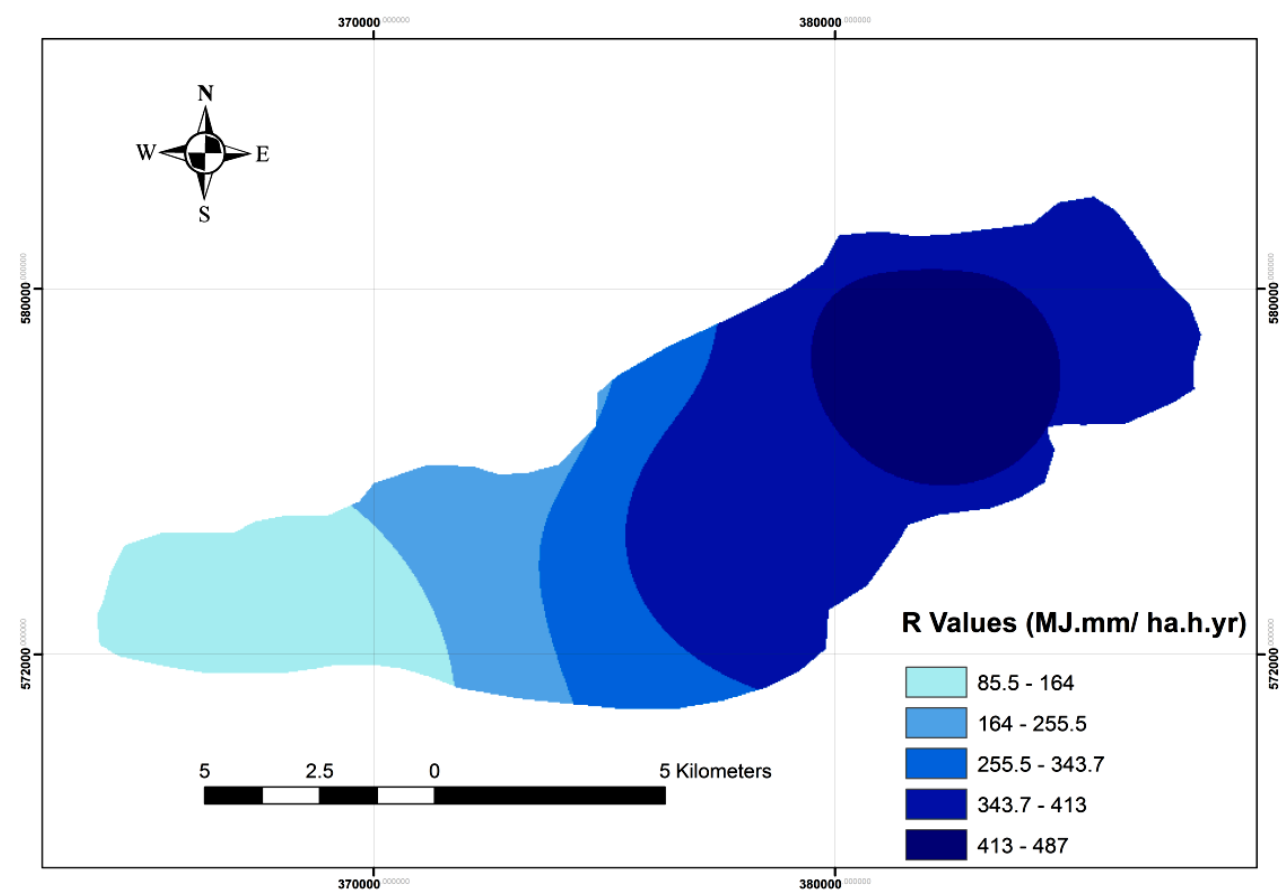

Figure 4. Spatial distribution of rainfall erosivity (R) factor.

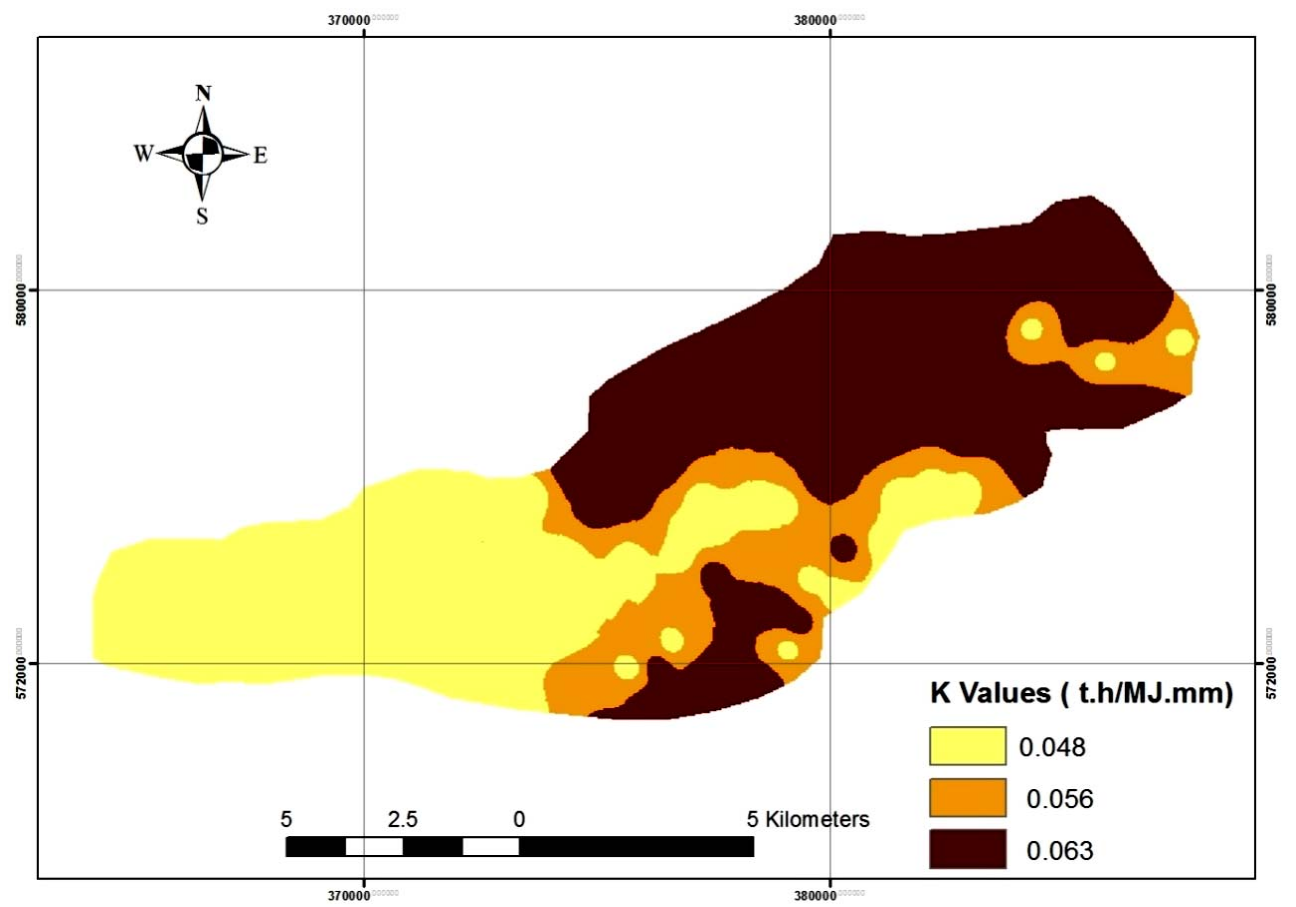

Figure 5. Spatial distribution of soil erodibility factor (K).

minimum $\mathrm{K}$ values is of $0.048 \mathrm{ton} \cdot \mathrm{ha} \cdot \mathrm{hr}^{-1} \cdot \mathrm{MJ}^{-1} \cdot \mathrm{mm}^{-1}$ in the lower catchment and associated with soils materials constituting the infill wadis/tributaries. The LS factor values in the watershed vary from low (0.0) to high (405.0). High LS values are associated with steep slopes greater than $15^{\circ}-20^{\circ}$ and $20^{\circ}-30^{\circ}$ slope category in the middle and upper reaches of the wadi. The low LS factor values associated with the alluvial fan surface and wadi/major tributary beds (Figure 6).

The magnitude and the spatial distribution of crop management factor $\mathrm{C}$ show values between 0.01 and 0.2 (Figure 7). The highest (poor land cover management) almost coincide with the lowest NDVI values, (0.22 $0.05)$, since forest protects soils against erosion, while 


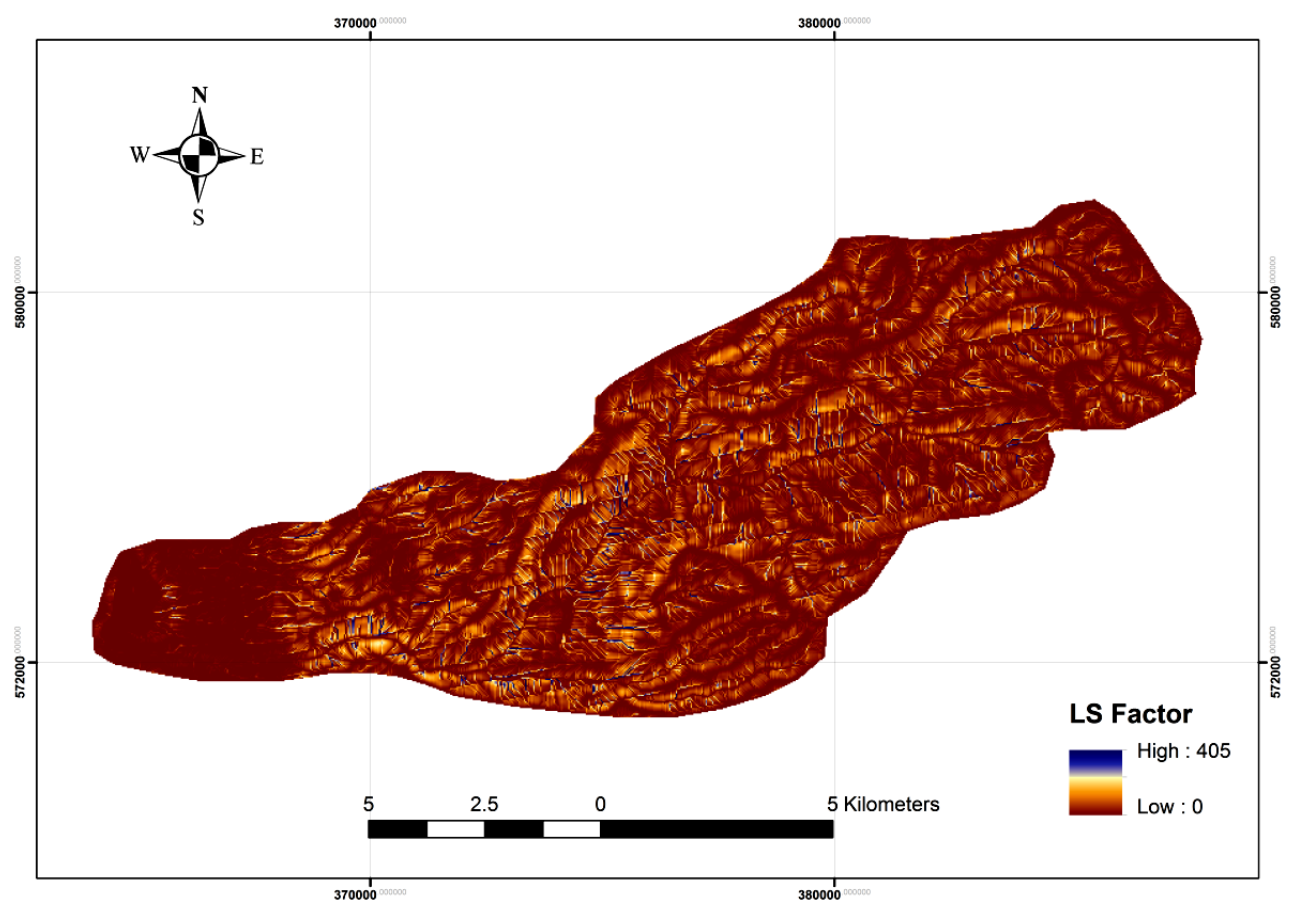

Figure 6. Spatial distribution of (LS) factor.

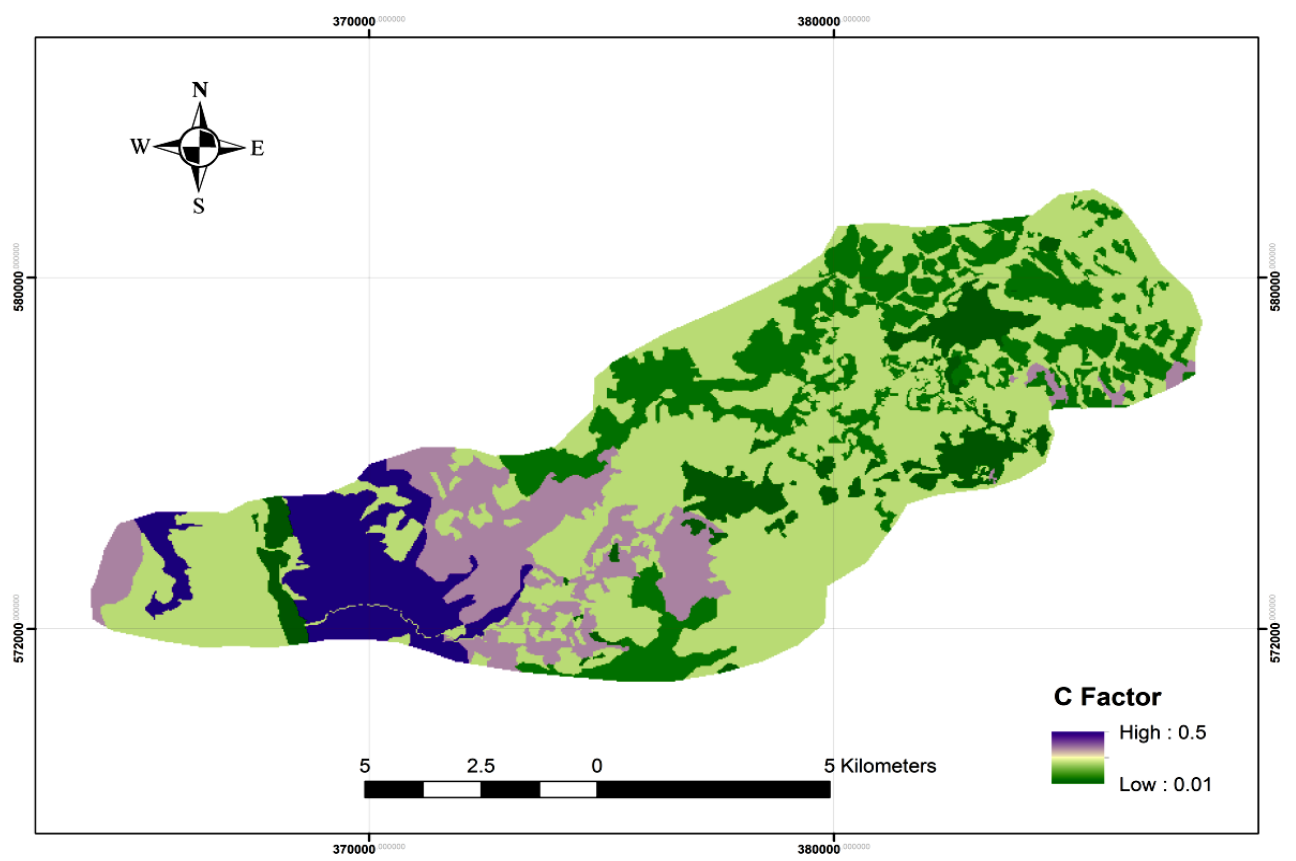

Figure 7. Spatial distribution of crop management (C) factor.

the open rangeland exposed to plowing has a high Cvalue (0.35). Similarly, the mixed rain-fed areas have a $\mathrm{C}$-value of (0.2). The model showed logical results after applying the assumed $\mathrm{C}$ values for each land-cover class, with a trend of increasing erosion with low vegetation cover.

By considering land use/cover-type and support factor, three classes of P factor were recognized (Figure 8). P factor ranges from 0.19 to 1.0 , the higher values in areas east of Krayma with no conservation practices (forest, natural vegetation), and other major settlements in the catchment. By contrast, maximum $\mathrm{P}$ values correspond to crop-land with relatively poor conservation practices in the upper and middle catchment.

$P$ values decrease towards the upper catchment, where in flat land units slope length decreases. This explained 


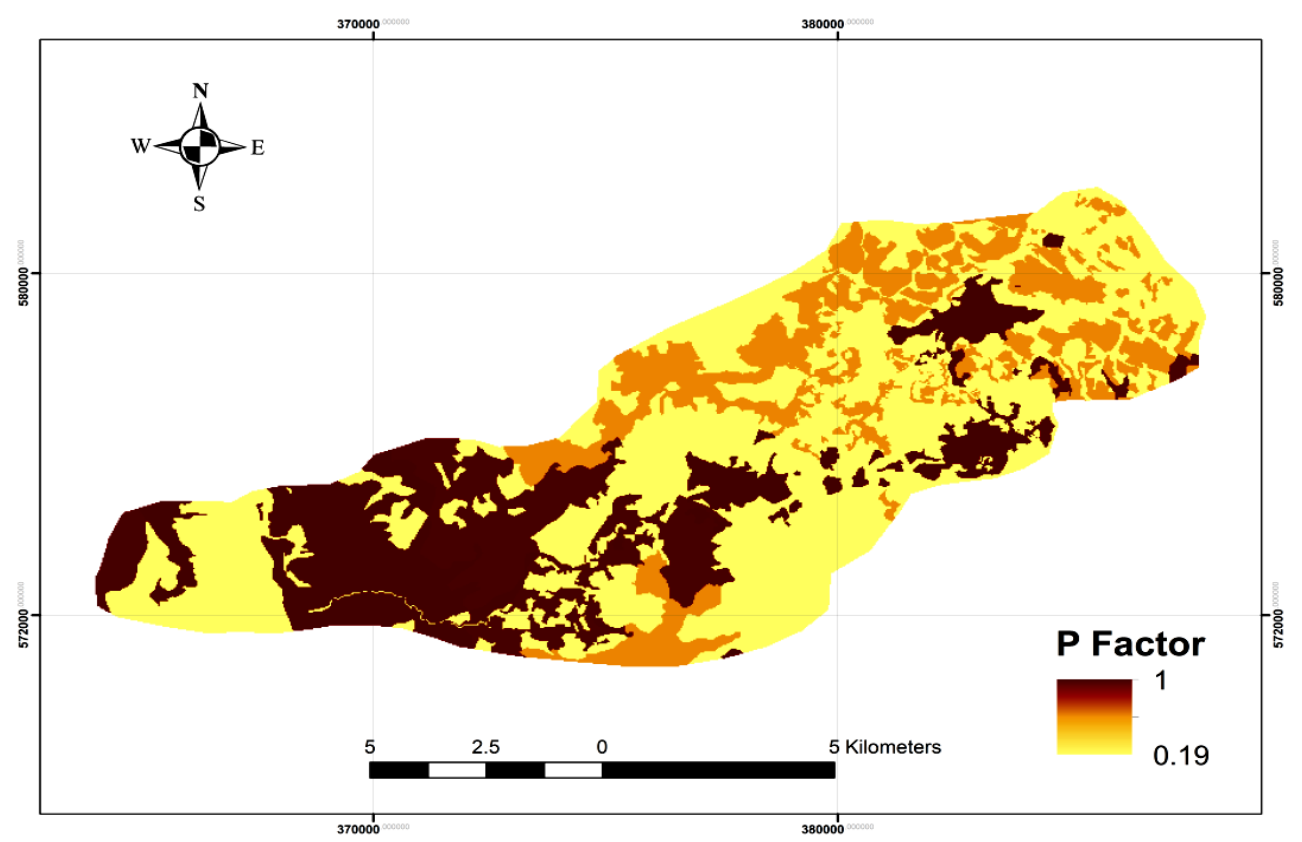

Figure 8. Spatial distribution of crop management (C) factor.

lower $\mathrm{P}$ values in the irrigated lands compared to open rangeland, since irrigated farms mainly occupy flat/undulating lands. Average annual soil loss of 10 ton $\cdot \mathrm{ha}^{-1} \cdot$ year $^{-1}$ was estimated for the whole catchment, and the final soil loss map compiled using the RUSLE model indicates a minimum of 0.0 to a maximum of 1865 ton $\cdot$ ha $^{-1} \cdot$ year $^{-1}$ (Figure 9).

Generally, if the estimated(A)value is high, it means a higher rate of sediment yield, while a lower value denotes a lower rate of sediment yield [47]. The Wadi Kufranja watershed was classified into five soil erosion risk categories (Figure 10). The area and proportion of soil erosion risk classes are illustrated in Table $\mathbf{5}$.

Potential soil erosion risk (Table 5) and severity (Table 6) increase from the upper to the lower reaches of the catchment. It is obvious that surface erosion can vary spatially due to rainfall variability, topographic and morphological changes, different soil types and characteristics, and human-induced disturbances. However, soil erosion is very severe between Krayma and Kufranja towns, and accounts for $31.2 \%$ of the total watershed soil loss.

The distrbution of risk classes and soil severity zones (Figures 10 and 11) show that $26.7 \%$ of the watershed has minimal soil loss, $36.5 \%$ is low, $5.6 \%$ and $7.9 \%$ is moderate and severe, while extreme soil erosion occupies $23.3 \%$ of the watershed. The highest soil loss values are clearly correlated with slope steepness. The upper and lower reaches of the wadi is dominated by moderate and steep slope categories: $10^{\circ}-15^{\circ}, 15^{\circ}-20^{\circ}$ and $20^{\circ}-30^{\circ}$. The first category makes up a minor portion of the total watershed. Gentle slopes are restricted only in the lower parts of the catchment which comprise the alluvial fan
Table 5. Area and proportion of each soil erosion risk class.

\begin{tabular}{cccc}
\hline $\begin{array}{c}\text { Erosion risk } \\
\text { class }\end{array}$ & $\begin{array}{c}\text { Numeric Range } \\
\left(\text { ton }^{-1} \mathrm{ha}^{-1} \cdot \mathrm{year}^{-1}\right)\end{array}$ & $\begin{array}{c}\text { Percentage } \\
(\%)\end{array}$ & $\begin{array}{c}\text { Area } \\
(\mathrm{ha})\end{array}$ \\
\hline Minimal & $0-5$ & 26.7 & 3372.21 \\
Low & $5-15$ & 36.5 & 4609.95 \\
Moderate & $15-25$ & 5.6 & 707.28 \\
Severe & $25-50$ & 7.9 & 997.77 \\
Extreme & $>50$ & 23.3 & 2942.79 \\
\hline
\end{tabular}

Table 6. Soil erosion severity zones.

\begin{tabular}{|c|c|c|c|}
\hline $\begin{array}{c}\text { Erosion } \\
\text { severity zone }\end{array}$ & $\begin{array}{l}\text { Numeric range } \\
\left(\text { ton }^{-1} \mathrm{ha}^{-1} \cdot \text { year }^{-1}\right)\end{array}$ & $\begin{array}{l}\text { Percentage } \\
\quad(\%)\end{array}$ & $\begin{array}{l}\text { Area } \\
\text { (ha) }\end{array}$ \\
\hline Slight & $0-5$ & 26.7 & 3372.21 \\
\hline Moderate & $15-25$ & 42.1 & 5317.23 \\
\hline Very Severe & $>25$ & 31.2 & 3940.56 \\
\hline
\end{tabular}

around Krayma, and the interfluve and col areas across the watershed. The second slope category comprises more than $75 \%$ of the area of the upper reaches. Slopes greater than $20^{\circ}-30^{\circ}$ and more create a distinctive pattern and are restricted to steep wadi side slopes. They emphasize the gorge-like nature along the main wadi course and major tributaries, thus the wadi floor is of difficult accessibility. Kufranja and Krayma areas are considered as highly erodible with potential erosion is more than 25 and $>50$ ton $\cdot$ ha $^{-1} \cdot$ year $^{-1}$.

The results of the present investigation in the Wadi Kufranja watershed are comparable with similar studies 


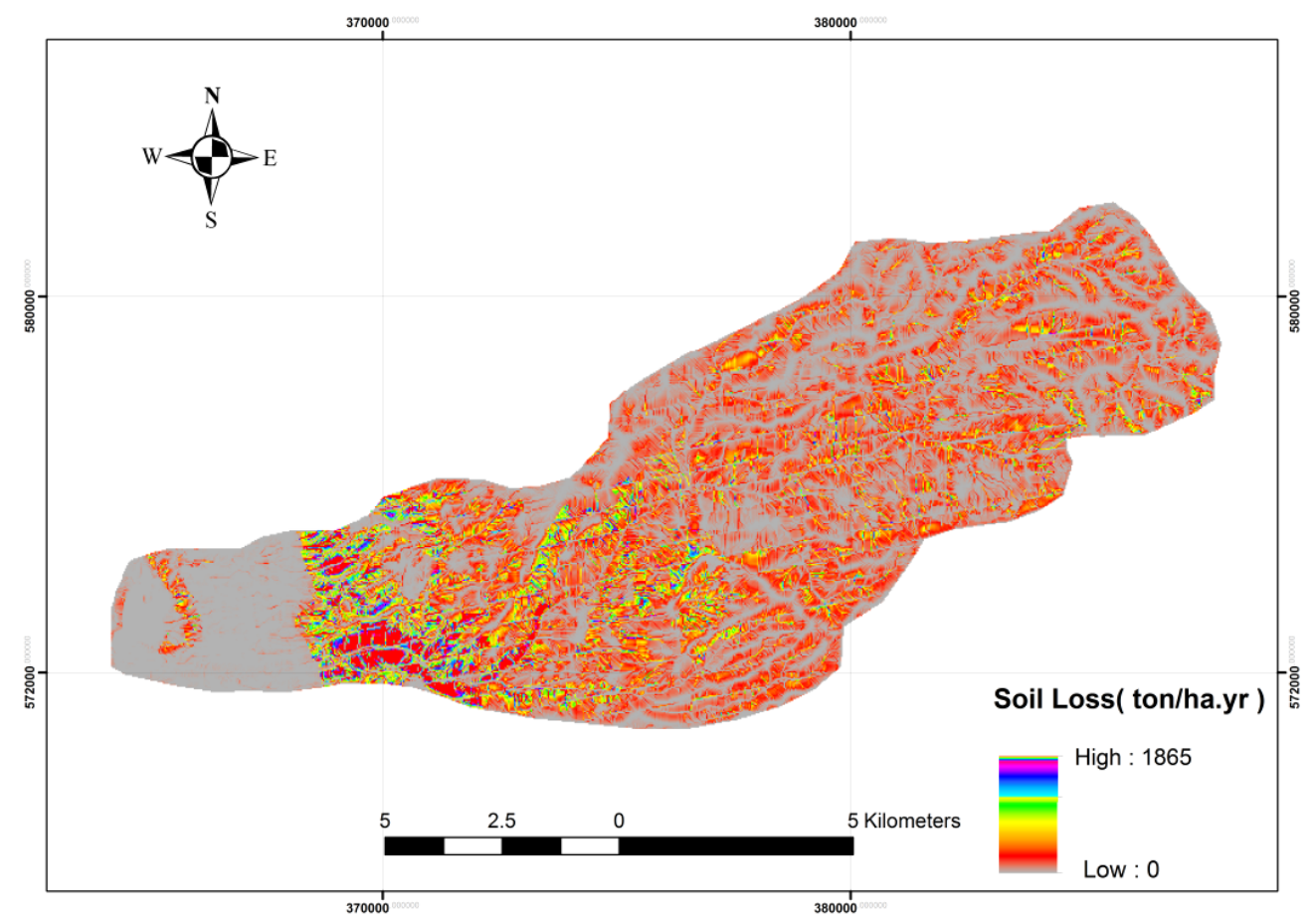

Figure 9. Spatial distribution of minimum and maximum soil loss $\left(\operatorname{ton}^{\circ} \mathrm{ha}^{-1} \cdot \mathrm{year}^{-1}\right)$.

elsewhere in central and northen Jordan [19,20,52], where similar terrain and climatic conditions, and historic land mismanagement prevail. Al-Alawi and Abujamous [19]

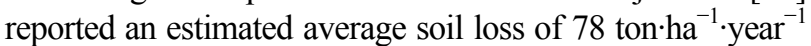
for a part of the Belqa district before installation of soil conservation structures. After 20 years of this construction and tree-planting, the predicted average soil loss decreased dramatically to an average of $33 \mathrm{ton} \cdot \mathrm{ha}^{-1} \cdot \mathrm{year}^{-1}$. Such encouraging results, therefore, emphasize the necessity for well-executed research on soil erosion and improved conservation methods.

The present results are also in consistent with those obtained from other Mediterranean watersheds of similar envionmental characteristics investigated elsewhere using the RUSLE model. The mean annual soil loss for nine watersheds in northwestern Crete, Greece [46] is predicted. The range is found from 77.174 ton $\cdot \mathrm{ha}^{-1} \cdot \mathrm{year}^{-1}$ and 205.467 ton ha $^{-1} \cdot$ year $^{-1}$. It has been reported that $77.5 \%$ of the Yialias area Cyprus is classified as low potential erosion risk $\left(20\right.$ ton $\left.\cdot \mathrm{ha}^{-1} \cdot \mathrm{year}^{-1}\right), 17.5 \%$ as moderate potential risk $\left(100\right.$ ton $\left.\cdot \mathrm{ha}^{-1} \cdot \mathrm{year}^{-1}\right)$, and only $5 \%$ as high risk $[60,61]$. On the contrary, Bonilla, et al. [62] reported lower figures from Central Chile. Under current conditions, low soil erosion rates were achieved and range from $<0.10$ ton $\cdot \mathrm{ha}^{-1} \cdot \mathrm{year}^{-1}$ to $6.1-8.0$ ton $\cdot \mathrm{ha}^{-1} \cdot \mathrm{year}^{-1}$, where $89 \%$ of the country is predicted to have low erosion rates, and no areas are affected by high soil loss compared to other Mediterranian countries. Similarly, Demirci and Karaburun [63] provided low figures regarding soil loss prediction for a watershed located in northwestern Turkey. The annual soil loss rate range from 1 ton $\cdot$ ha $^{-1} \cdot$ year $^{-1}$ to $>10$ ton $\cdot$ ha $^{-1} \cdot$ year $^{-1}$. By contrast, in South Africa, Mhangara, et al. [29] reported that the Keiskamma catchment is exposed to excessive rates of soil loss due to high soil erodibility, steep slopes, poor conservation practices, and low vegetation cover $0.65 \%$ of the catchment shows very low to moderate levels of soil loss $\left(<25\right.$ ton $\left.\cdot \mathrm{ha}^{-1} \cdot \mathrm{year}^{-1}\right)$, and $35 \%$ of the catchment is prone to high to extremely high soil loss $(>25$ ton $\cdot \mathrm{ha}^{-1} \cdot$ year $\left.^{-1}\right)$. More comparable results on soil erosion potential with central and northern Jordan, are obtained for Foupana river watershed in Algarave (Mediterranean Portugal) [64], and Nisava river watershed (Southerneast Serbia), not far from the Mediterranean [65]. Potential erosion across Foupana watershed was estimated between 76 to 99 ton $^{-h^{-1}}{ }^{-}$year ${ }^{-1}$. The rest of the area has a low to moderate risk of erosion (14 to 60 ton $\cdot \mathrm{ha}^{-1} \cdot \mathrm{year}^{-1}$ ). The average annual soil loss for Nisava river watershed was estimated at $27 \mathrm{ton} \cdot \mathrm{ha}^{-1} \cdot \mathrm{year}^{-1}$, thus classified under very high erosion rate category. Severe erosion rate (40 80 ton $\cdot \mathrm{ha}^{-1} \cdot \mathrm{year}^{-1}$ ) was observed at $14.2 \%$ of the watershed, whereas very severe erosion rate $\left(>80\right.$ ton $\left.\cdot \mathrm{ha}^{-1} \cdot \mathrm{year}^{-1}\right)$ described about $7.8 \%$ of the watershed. Soil erosion rates are found to be high over most parts of the catchment; consequently, implementation of effective soil conservation measures is required to reduce soil erosion.

The upper part of the watershed is forested with mixed rainfed agriculture. Population growth, overgrazing, cropland expansion, and human activities have result in 


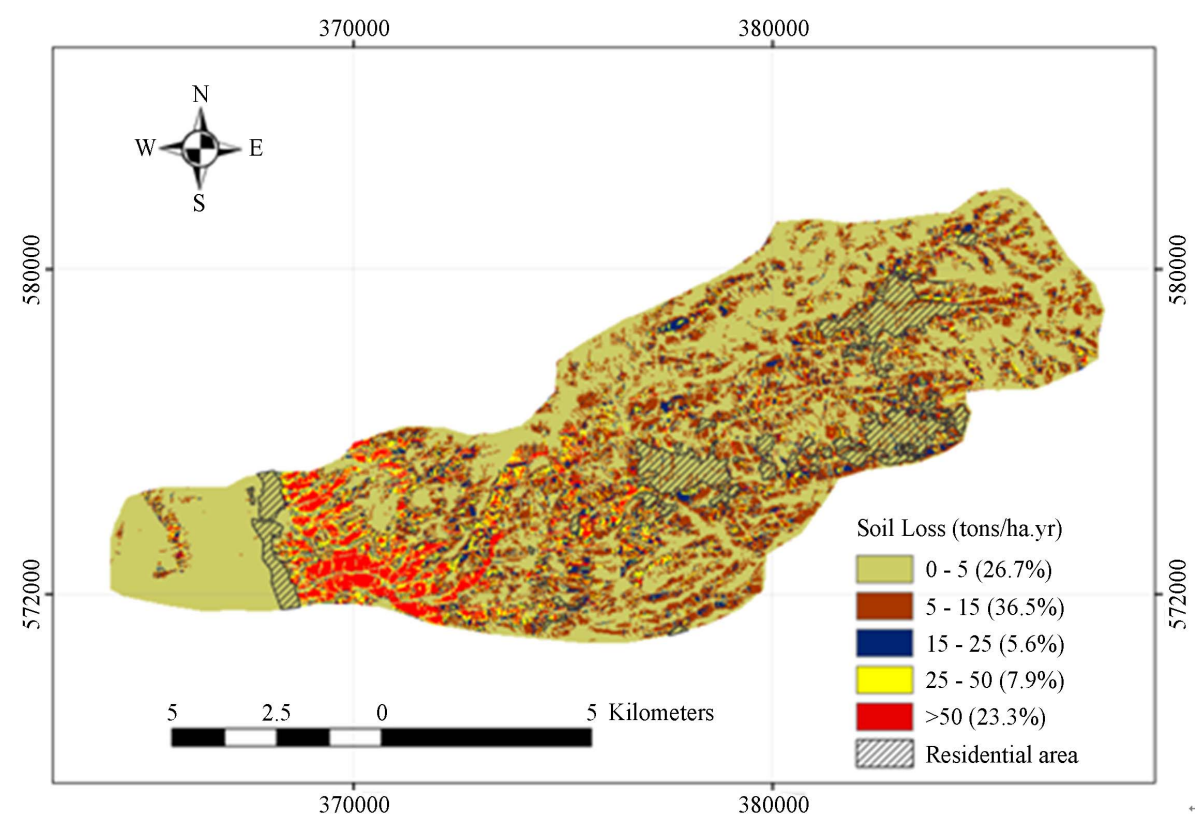

Figure 10. Spatial distribution of erosion risk categories.

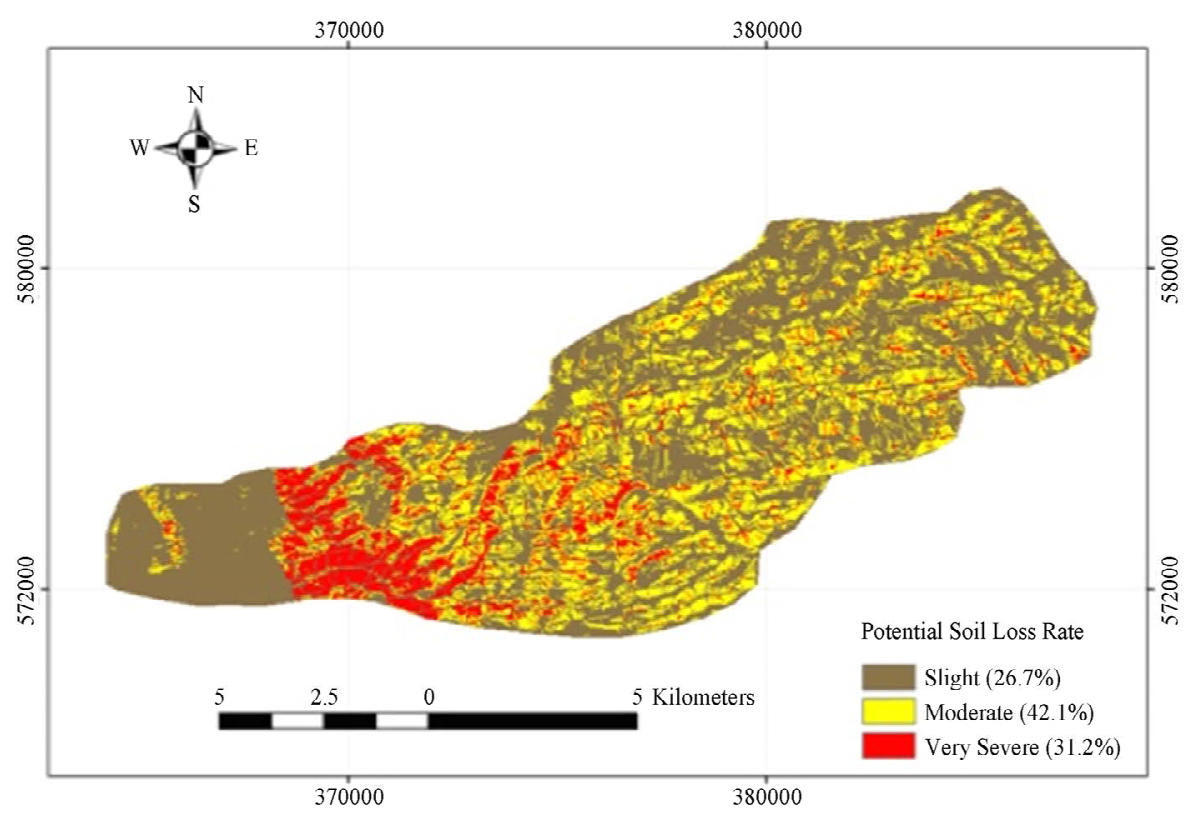

Figure 11. Spatial distribution of soil erosion severity zones.

widespread removal of vegetation cover. Between 1978 and 2010, prominent changes in land cover/land use were taken place across Wadi Kufranja [28]. Among these changes was a dramatic increase of cultivated lands from $9.98 \%$ of the catchment area in 1978 to $51.23 \%$ in 2010 ), due to high rates of population growth. The residential areas also increase from $1.5 \%$ of the catchment area in 1978 to $7.52 \%$ in 2010 . Therefore, forested areas around the settlements have been decreased or removed completely. On the contrary, small scattered areas of rangeland and bare land where transformed to forest, thus for- est land increased from $13.38 \%$ of the catchment area in 1978 to $18.53 \%$ in 2010 . Due to land cover/land use changes and climatic change in Jordan over the last several decades, soil erosion rates across Wadi Kufranja, and other parts of northern Jordan have been changed [66]. Accordingly, soil erosion becoming more serious on moderate and steep slopes transformed into cultivated or range land. Therefore, the expansion of cultivated cereals increase the susceptibility of soils to erosion, and the cultivated lands with poor conservation measure exhibit higher rate of soil erosion and decline in soil fertility. 
Minimal vegetation cover dominated the steep and long slopes in the middle and lower parts of the cathment. Slopes over $15^{\circ}$ are commonly cultivated, and plowing with animals has been observed on steep slopes as $25^{\circ}$ and more.

It is postulated elsewhere that the RUSLE parameters can be altered significantly by human activities [29]. The $\mathrm{C}$ and $\mathrm{P}$ factors can be improved to reduce the soil erosion loss through afforestation and shifting community environmental practice. The LS factor also can be modified by shortening the length and steepness of slopes by the construction of contour walls and stone terraces. Construction of soil conservation measures is vital to control runoff and soil erosion across different agroecological zones and under varouis land uses. Expected benefits of enhancing soil and water conservation in the studied area could be summarized in the following: control of upland soil erosion; reduction in sediment load of Wadi Kufranja; and reducing the peak flows of the wadi [67]. Also, the construction of check dams along gullies is an essential measure to minimize gully erosion. The integration of trees in farmland and rangeland will act as appropriate coverage and a protector for soil from rainfall energy, and through stabilizing the soil structure against sheet and gully erosion. Steep slopes may be suitable for grazing and forest plantation. Moderate and slightly steep slopes could be utilized for tree crops, and the wadi bottom (accessible strips) for growing vegetables, and the flat summits and gentle structural benches may be allocated for cereals farming. The results of soil erosion risk, severity, and land use/cover-type can assist decision-makers in identification of priority areas in urgent need of conservation and land-management plans. The aforementioned measures must be implemented through the government and the participation of the farmers and villagers living across the watershed. However, the figures obtained regarding soil loss and severity are disturbing, considering that the Ministry of Water and Irrigation began construction of a dam west of Kufranja which will collect storm-water runoff and base-flow. Annual sediment yield of the catchment contributing to the reservoir has not been determined by the Ministry of Water and Irrigation [60], and in light of the present results, the predicted large sediment yield will seriously threaten the life of the reservoir behind this dam.

\section{Conclusion}

The present determination of RUSLE parameters for the Wadi Kufranja basin has revealed the severity of soil erosion. The computed soil erosion rate compares comfortably with estimates reported for other areas in northern Jordan and elsewhere, thus validating the RUSLE model. The mean soil loss estimated for the watershed was 10 ton $\cdot \mathrm{ha}^{-1} \cdot \mathrm{year}^{-1}$, with the five erosion risk classes, ranging from 0.0 to 1865 ton $\cdot \mathrm{ha}^{-1} \cdot \mathrm{year}^{-1}$. Areas of $53.1723 \mathrm{~km}^{2}$ (5317.23 hectares) and $39.4056 \mathrm{~km}^{2}$ (3940.56 hectares) were classed as suffering moderate or very severe soil erosion. These areas in Wadi Kufranja catchment, and other similar areas in northern and central Jordan should therefore be prioritized for conservation. Similarly, spatial analysis denoted high soil erosion rates in the middle and lower reaches of the catchment. Here, long and continuous human disturbance and deforestation, with the combined effect of K, LS, and C factors, account for high soil erosion loss across the study area. Further research should focus on soil erosion parameters in the rainfed highland region of the country. More data on rainfall and its duration and intensity provided a basis for calculating erosive of rainfall. Field measurements of rainfall erosion (direct measurements and simulated rainfall) are highly recommended, and the results should be compared against soil loss figures obtained by the RUSLE and other predicting models. Finally, the present investigation has demonstrated that GIS and RS techniques are simple and low-cost tools for modeling soil erosion, with the purpose of assessing erosion potential and risk for the watersheds of northern Jordan.

\section{Acknowledgements}

This work is part of a research project funded by the Faculty of Scientific Research, The University of Jordan, Amman, Jordan.

\section{REFERENCES}

[1] P. Beaumont and K. Atkinson, "Soil Erosion and Conservation in Northern Jordan," Journal of Soil and Water Conservation, Vol. 24, No. 4, 1969, pp. 144-147.

[2] M. Al-Kaisi, "Soil Erosion: An Agricultural Production Challenge," Integrated Crop Management, Vol. 19, 2000, pp. 141-143.

[3] A. Battikhi and S. Arabiat, "Constraints to the Successful Application of Modern Technology for Soil Conservation in Jordan. Part-Environmental Features and Extent of Erosion," Dirasat Research Journal, Vol. 10, No. 2, 1983, pp. 129-165.

[4] Natural Resources Authority, "Soil Erosion in the East Ghor Region," Amman, 1965.

[5] McDonald Partners and Hunting Technical Services Ltd., "East Bank Water Resources Summary Report," Central Water Authority, Amman, 1965.

[6] FAO, UNEP and UNESCO, "A Provisional Methodology for Soil Degradation Assessment," FAO, Rome, 1979.

[7] Harza, "Report on Dam Heightening," Jordan Valley Authority, Amman, 1980.

[8] J. H. Lara, "The 1980 Sedimentation Survey of King Talal Reservoir," Jordan Valley Authority, Denver/Amman, 1980.

[9] R. Morgan, "Soil Erosion," Topics in Applied Geography. 
Longman, London, 1977.

[10] R. Morgan, "Soil Erosion in the United Kingdom: Field Studies in the Silsoe Area 1973-1975," Occasional Paper No. 4, National College of Agricultural Engineering, London, 1977.

[11] I. Dabbas, "Soil Erosion Measurement in the Salt area, Jordan," M.A Thesis, University of Jordan, Amman, 1994.

[12] A. Jawabeh, "Soil Erosion Measurements in the Muwaqar Area, Jordan," M.A Thesis, University of Jordan, Amman, 1995.

[13] A. Al-Hamdan, "Soil Erosion Measurements in the Azraq Area, Jordan," M.A Thesis, University of Jordan, Amman, 1996.

[14] M. Abu-Helo, "Soil Erosion Susceptibility in the Baqa Depression, Jordan," M.A Thesis, University of Jordan, Amman, 1985.

[15] M. Daher, "Soil Erosion Susceptibility of Wadi Shueib, Jordan," M.A Thesis University of Jordan, Amman, 1988.

[16] O. Mazawdeh, "Soil Erosion Susceptibility of Wadi AlShalala, Jordan," M.A Thesis, University of Jordan, Amman, 2013.

[17] R. Van Zuidam, "Terrain Analysis and Classification Using Aerial Photographs: A Geomorphological Approach," ITC, Enschede, 1979.

[18] R. Van Zuidam, "Aerial Photo-Interpretation in Terrain Analysis and Geomorphological Mapping," Smits Publishers, The Hague, 1985.

[19] M. Al-Alawi and M. Abujamous, "Estimation of Soil Erosion in Jordan by Using GIS," In: R. De Amicis, et al., Eds., GeoSpatial Visual Analytics: Geographical Information Processing and Visual Analytics for Environmental Security, Springer Science \& Business Media, Berlin, Springer-Verlag B.V., 2009, pp. 439-450.

[20] I. A. Farhan and F. T. Al-Bakri, "Use of GIS and Remote Sensing to Assess Soil Erosion in an Arid to Semiarid Basin in Jordan," Proceedings of the International Conference on Sediment Transport: Modeling in Hydrological Watersheds and Rivers, Istanbul, 2012, pp. 145-152.

[21] F. Al-Zitawi, "Using RUSLE in Prediction of Soil Loss for Selected Sites in North and North West of Jordan," M.S Thesis, Jordan University of Science and Technology, Irbid, 2006.

[22] A. M. Quennell, "The Structure and Geomorphic Evolution of the Dead Sea Rift," Quarterly Journal of the Geological Society, Vol. 114, No. 1-4, 1958, pp. 1-24. http://dx.doi.org/10.1144/gsigs.114.1.0001

[23] Y. Farhan, "Landslides in Central Jordan with Special Reference to the March 1983 Rainstorm," Singapore Journal of Tropical Geography, Vol. 7, No. 2, 1986, pp. 8096. http://dx.doi.org/10.1111/j.1467-9493.1986.tb00174.x

[24] W. Fisher, K. Atkinson, P. Beaumont, A. Coles and D. Gilchrist-Shirlaw, "Soil Survey of Wadi Zeqlab, Jordan," University of Durham, Durham, 1966.

[25] W. Fisher, H. Bowen-Jones, K. Atkinson, P. Beaumont, K. Smith and J. Stevens, "Soil and Land Potential Survey of the Highlands of North-West Jordan," University of Durham, Durham, 1969.
[26] Y. Farhan, "Slope Stability Problems in Central and Northern Jordan," The Arab World Geographer, Vol. 5, No. 4, 2002, pp. 265-290.

[27] K. Atkinson and P. Beaumont, "The Forests of Jordan," Economic Botany, Vol. 25, No. 3, 1971, pp. 305-311. http://dx.doi.org/10.1007/BF02860765

[28] D. Zregat, "Analysis of Forest Land-Cover Changes in Wadi Kufranja, Jordan (1978-2010) Using GIS and RS Techniques," in press, 2013.

[29] P. Mhangara, V. Kakembo and K. Lim, "Soil Erosion Risk Assessment of the Keiskamma Catchment, South Africa Using GIS and Remote Sensing," Environmental Earth Science, Vol. 65, No. 7, 2012, pp. 2087-2102. http://dx.doi.org/10.1007/s12665-011-1190-x

[30] V. Prasannakumar, H. Vijith, S. Abinod and N. Geetha, "Estimation of Soil Erosion Risk within a Small Mountainous Sub-Watershed in Kerala, India, Using Revised Universl Soil Loss Equation (RUSLE) and Geo-Information Technology," Geoscience Frontiers, Vol. 3, No. 2, 2012, pp. 209-215. http://dx.doi.org/10.1016/j.gsf.2011.11.003

[31] W. H. Wischmeier and D. D. Smith, "Predicting Rainfall Erosion Losses from Cropland East of the Rocky Mountains," Agricultral Handbook No. 282, Agricultural Research Service, US Department of Agriculture, Purdue Agricultural Experimental Station, 1965.

[32] W. H. Wischmeier and D. D. Smith, "Predicting Rainfall Erosion Losses: A Guide to Conservation Planning," Agricultural Handbook No. 537, US Department of Agriculture, Washington DC, 1978.

[33] R. Morgan, J. Quinton, R. Smith, G. Govers, J. Poesen, K. Auerswald, G. Chisci, D. Torri and M. Styezen, "The European Soil Erosion Model (EUROSEM): A Dynamic Approach for Predicting Sediment Transport from Fields and Small Catchments," Earth Surface Processes and Landforms, Vol. 23, 1998, pp. 527-544.

http://dx.doi.org/10.1002/(SICI)1096-9837(199806)23:6< 527::AID-ESP868>3.0.CO;2-5

[34] S. De Jong, M. Paracchini, F. Bertolo, S. Folving, J. Megier and A. De Roo, "Regional Assessment of Soil Erosion Using the Distributed Model SEMMED and Remotely Sensed Data," Catena, Vol. 37, 1999, pp. 291-308. http://dx.doi.org/10.1016/S0341-8162(99)00038-7

[35] D. A. Flanagan and M. A. Nearing, "USDA Water Erosion Prediction Project: Hillslope Profile and Watershed Model Documentation," USDA-ARS, National Soil Erosion Research Laboratory, West Lafayette, 1995.

[36] J. Ascough, C. Baffaut, M. Nearing and B. Liu, "The WEPP Watershed Model: I. Hydrology and Erosion," Transactions of the American Society of Agricultural and Biological Engineers, Vol. 40, No. 4, 1997, pp. 921-933. http://dx.doi.org/10.13031/2013.21343

[37] J. G. Arnold, R. Srinivasan, R. Muttiah and J. R. Williams, "Large Areas Hydrologic Modeling and Assessment Part I: Model Development," Journal of the American Water Resources Association, Vol. 34, No. 1, 1998, pp. 73-89. http://dx.doi.org/10.1111/j.1752-1688.1998.tb05961.x

[38] R. P. Rudra, W. T. Dickinson and G. J. Wall, “Application of the CREAMS Model in Southern Ontario Condi- 
tions," Transactions of the American Society of Agricultural and Biological Engineers, Vol. 28, No. 4, 1985, pp. 1233-1240. http://dx.doi.org/10.13031/2013.32417

[39] K. G. Renard, G. R. Foster, G. A. Weesies and J. P. Porter, "RUSLE: Revised Universal Soil Loss Equation," Journal of Soil and Water Conservation, Vol. 46, No. 1, 1991, pp. 30-33.

[40] K. G. Renard, G. R. Foster, D. C. Yoder and D. K. McCool, "RUSLE Revisited: Status, Questions, Answers and the Future," Journal of Soil and Water Conservation, Vol. 49, No. 3, 1994, pp. 213-220.

[41] K. G. Renard, G. R. Foster, G. A. Weesies, D. K. McCool and D. C. Yoder, "Predicting Soil Erosion by Water: A Guide to Conservation Planning with the Revised Universal Soil Loss Equation (RUSLE)," Agricultural Handbook No. 703, US Department of Agriculture, Washington DC, 1997.

[42] K. C. Bhadur, "Mapping Soil Erosion Susceptibility Using Remote Sensing and GIS: A Case of the Upper Nam Wa Watershed, Nan Province, Thailand," Environmental Geology, Vol. 57, No. 3, 2009, pp. 695-705. http://dx.doi.org/10.1007/s00254-008-1348-3

[43] G. Fu, S. Chen and D. McCool, "Modelling the Impacts of No-Tillage Practices on Soil Erosion and Sediment Sield with RUSLE, SEDD and Arc View GIS," Soil and Tillage Research, Vol. 85, No. 1-2, 2006, pp. 38-49. http://dx.doi.org/10.1016/j.still.2004.11.009

[44] A. Pandey, V. Chowdary and B. C. Mal, "Identification of Critical Erosion Prone Areas in the Small Agricultural Watershed Using USLE, GIS and Remote Sensing," Water Resources Management, Vol. 21, No. 4, 2007, pp. 729746. http://dx.doi.org/10.1007/s11269-006-9061-z

[45] A. Pandey, S. K. Mathur, S. K. Mishra and B. C. Mal, "Soil Erosion Modeling of a Himalayan Watershed Using RS and GIS," Environmental Earth Sciences, Vol. 59, No. 2, 2009, pp. 399-410. http://dx.doi.org/10.1007/s12665-009-0038-0

[46] M. Kouli, P. Soupio and F. Vallianatos, "Soil Erosion Prediction Using the Revised Universal Soil Loss Equation (RUSLE) in a GIS Framework, Chania, Northwestern Crete, Greece," Environmental Geology, Vol. 57, No. 3, 2009, pp. 483-497. http://dx.doi.org/10.1007/s00254-008-1318-9

[47] V. Prasannakumar, H. Vijith, N. Geetha and R. Shiny, "Regional Scale Erosion Assessment of a Sub-Tropical Highland Segment in the Western Ghats of Kera, South India," Water Resources Management, Vol. 25, No. 14, 2011, pp. 3715-3727. http://dx.doi.org/10.1007/s11269-011-9878-y

[48] V. Prasannakumar, R. Shiny, N. Geetha and H. Vijith, "Spatial Prediction of Soil Erosion Risk by Remote Sensing, GIS and RUSLE Approach: A Case Study of Siruvani River Watershed in Attapady Valley, Kerala, India," Environmental Earth Science, Vol. 64, No. 4, 2011, pp. 965972. http://dx.doi.org/10.1007/s12665-011-0913-3

[49] A. Millward and J. E. Mersey, "Adapting the RUSLE to Model Soil Erosion Potential in a Mountainous Tropical Watershed," CATENA, Vol. 38, No. 2, 1999, pp. 109-129. http://dx.doi.org/10.1016/S0341-8162(99)00067-3

[50] Ministry of Agriculture (Jordan), "The Soil of Jordan. Report of the National Soil Map and Land Use Project," Hunting Technical Services Ltd. and European Commission,
1995.

[51] N. I. Eltaif, M. A. Gharaibeh, F. Al-Zaitawi and M. N. Alhamad, "Approximation of Rainfall Erosivity Factors in North Jordan," Pedosphere, Vol. 20, No. 6, 2010, pp. 711-717. http://dx.doi.org/10.1016/S1002-0160(10)60061-6

[52] G. R. Foster, D. K. McCool, K. G. Renard and W. C. Moldenhawer, "Conversion of the Universal Soil Loss Equation to SI Metric Units," Journal of Soil and Water Conservation, Vol. 36, No. 6, 1981, pp. 355-359.

[53] W. J. Edmonds, P. G Thomas, T. W. Simpson and J. C. Baker, "Soil and Land Use Interpretation," In: W. J. Edmonds, P. G Thomas, T. W. Simpson and J. C. Baker, Eds., Land Judging and Soil Evaluation, Blacksberg, 1998.

[54] H. Mitasova, J. Hofierka, M. Zlocha and R. Iverson, "Modeling Topographic Potential for Erosion and Deposition Using GIS," International Journal of Geographical Information Systems, Vol. 10, No. 5, 1996, pp. 629-641.

[55] H. Zhang, Q. Yang, R. Li, Q. Liu, D. Moore, P. He, C. Ritsema and V. Geissen, "Extension of a GIS Procedure for Calculating the RUSLE Equation LS Factor," Computers and Geoscences, Vol. 52, No. 1, 2013, pp. 177-188. http://dx.doi.org/10.1016/j.cageo.2012.09.027

[56] E. Roose, "Land Husbandry-Components and Strategy," UN/FAO Soils Bulletin 70, Montpellier, 1996.

[57] S. Essa, "GIS Modeling of Land Degradation in Northern Jordan Using LANDSAT Imagery," Ph.D. Dissertation, United Arab Emirates University, Al-Ain, 2004.

[58] C.-Y. Lin, W.-T. Lin and W.-C. Chou, "Soil Erosion Prediction and Sediment Yield Estimation: The Taiwan Experience," Soil and Tillage Research, Vol. 68, No. 2, 2002, pp. 143-152. http://dx.doi.org/10.1016/S0167-1987(02)00114-9

[59] A. Rabia, "Mapping Soil Erosion Risk Using RUSLE, GIS and Remote Sensing Techniques," 4th International Congress of ECSSS, EUROSOIL, Bari, 2-6 June 2012, p. 1082.

[60] Ministry of Water and Irrigation-Jordan Valley Authority, "Final Design for the Construction of Kufranja Dam," Energoprojekt, Belgrade, 2010.

[61] D. Alexakis, D. Hadjimitsis and A. Agapiou, "Integrated Use of Remote Sensing, GIS and Precipitation Data for the Assessment of Soil Erosion Rate in the Catchment Area of Yialias in Cyprus," Atmospheric Research, Vol. 131, No. 10, 2013, pp. 108-124. http://dx.doi.org/10.1016/j.atmosres.2013.02.013

[62] C. A. Bonilla, J. T. Reyes and A. Magri, "Water Erosion Prediction Using the Revised Universal Soil Loss Equation (RUSLE) in a GIS Framework, Central Chile," Chilean Journal of Agricultural Research, Vol. 70, No. 1, 2010, pp. 159-169.

http://dx.doi.org/10.4067/S0718-58392010000100017

[63] A. Demirci and A. Karaburun, "Estimation of Soil Erosion Using RUSLE in a GIS Framework: A Case Study in the Buyukcekmece LakeWatershed, Northwest Turkey,' Environmental Earth Sciences, Vol. 66, No. 3, 2012, pp. 903-913. http://dx.doi.org/10.1007/s12665-011-1300-9

[64] T. Panagopoulos and V. Ferreira, "Erosion Risk Map of a 
Foupana River Watershed in Algarve, Portugal," Transactions on Environment and Development, Vol. 6, No. 9, 2010, pp. 635-644.

[65] V. Perovic, L. Zivotic, R. Kadovic, D. Jaramaz, V. Mrvic and M. Todorovic, "Spatial Modeling of Soil Erosion Potential in a Mountainous Watershed of South-Eastern Serbia," Environment Earth Sciences, Vol. 68, No. 1, 2013, pp. $115-128$.

http://dx.doi.org/10.1007/s12665-012-1720-1
[66] M. Alkharabsheh, T. K. Alexandridis, G. Bilas, N. Misopolinos and N. Silleos, "Impact of Land Cover Change on Soil Erosion Hazard in Northern Jordan Using Remote Sensing and GIS," Procedia Environmental Sciences, Vol. 19, No. 3, 2013, pp. 912-921.

http://dx.doi.org/10.1016/j.proenv.2013.06.101

[67] S. El-Swaify and H. Hurni, "Transboundary Effects of Soil Erosion and Conservation in the Nile Basin," Land Husbandry, Vol. 1, No. 1-2, 1996, pp. 7-21. 